\title{
EXPERIENCE CLASSIFICATION AND LINGUISTIC DISTRIBUTION
}

\author{
Yao Shen \\ University of Michigan
}

Every speech community has its own language. Each language is capable of expressing the overt life experience of its speech community. Two speech communities can have similar meaning experiences, and their languages can have similar linguistic categories. Similar meaning experiences, however, can have different experience classification. And difference in experience classification can thus result in different distribution in similar linguistic categories.

In for eign language learning, differences between languages are always learning difficulties. Language teachers, however, dare not relax in the blissful belief that similarities between languages pose no teaching problems. There can be similar phonemes between languages. But there can also be different allophones ${ }^{1}$ and different arrangements of phonemes; ${ }^{2}$ hence "similar" phonemes also pose teaching problems. In this article we shall see that one similarity in meaning, one similarity in grammar, and one similarity in meaning and grammar may be teaching problems too, due to differences in distribution. The languages are American English and Mandarin Chinese.

Example 1. Meaning: four weather expressions.

Four expressions commonly used in Ann Arbor, Michigan, U.S.A., in connection with the weather are hot, warm, cool, and cold. In English, the following is usually heard during summer:

1. It's hot today

2. It's warm today
3. It's cool today

4. It's cold today (rare)

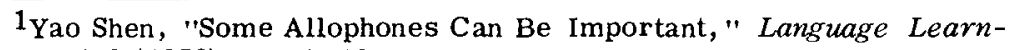
ing, IX, 1-2 (1959), pp. 7-18.

2Yao Shen, "Phonemic Charts Alone Are Not Enough," Language Learning, V, 3-4 (1955), pp. 122-129. 
However, during winter, one usually does not hear the third one:

1. It's hot today (rare)

2. It's warm today

3. - -

4. It's cold today

There is always a difference in temperature among hot, warm, cool, and cold in the same locality but in different seasons, in different localities but in the same season, or in different localities and different seasons experienced by speakers of the same language. Our interest here is the usage of these four weather expressions in the same locality and in the same season but by speakers of different languages: English and Chinese.

In Chinese, there are also four weather expressions. They are: rè, nwănhwo, lyángkwai, and lèng. If we put the four weather expressions in English and in Chinese side by side, we have:

English

hot

warm

cool

cold

\section{Chinese}

rè

nwănhwo

lyángkwai

lěng

The four expressions in Chinese are near equivalents to the four in English as items, but not quite. In Ann Arbor, warm can be said to have a higher temperature than cool. Between the two poles of hot and cold, warm is closer to hot and cool is closer to cold, regardless of the fact whether the temperature is moving from hot toward cold (getting cooler or colder) or from cold toward hot (getting warm). We may indicate them in the following way:

hot
warm
cool
cold

In Chinese, lyángkwai (cool) and nwănhwo (warm) are experienced differently. From rè (hot) to lěng (cold), the state of warm $=$ cooler is lyängkwai. Thus we have: 
rè

lyángkwai

lěng

From lèng (cold) to rè (hot), the state of cool = warmer is nwănhwo.

Thus we have:

rè

nwănhwo

lěng

We may represent cool, warm, lyángkwai, nwănhwo in the following way:

English

hot

warm

cool

cold

$$
\uparrow
$$

The relationship of these four items in English and in Chinese can be so approximated: ${ }^{3}$

\section{Chinese}

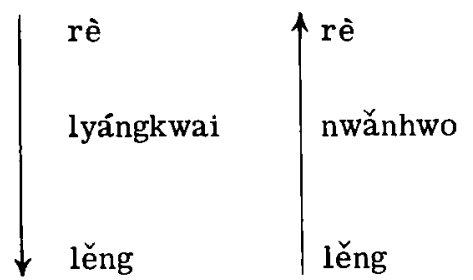

$3_{\text {If }}$ we put Tagalog, English, and Chinese side by side, we have:

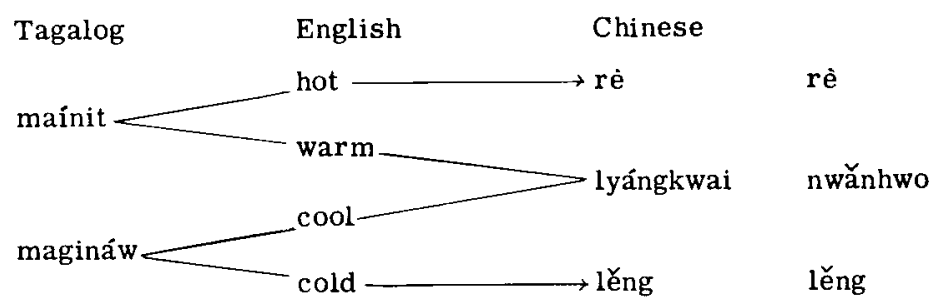

See Yao Shen, "Some Functions of Pattern Practice," The MST English Quarterly (Manila, the Philippines), VIII, 1 (1958), p. 14. 
English

Chinese

hot

rè

rè

warm

cool

lyángkwai

nwănhwo

cold

lěng

lěng

If we look at the distribution of these items in English, we can say that within the two poles of hot and cold, there are two directions: from hot to cold, and from cold to hot. Between the two points, there are warm and cool making a total of four reversible points of reference among themselves. Between $r \grave{e}$ and lèng, there are in Chinese two continuous non-reversible directions. lyángkwai and nwănhwo are in seasonal complementary distribution with no reference to each other. Each has its specific relation to ré and lèng. Although there are four weather expressions, there are only three points of reference with lyángkwai and nwănhwo indicating the change of direction of temperature. We can now represent the four items in English and in Chinese in the following way:

English

Chinese

hot
warm
cool
cold

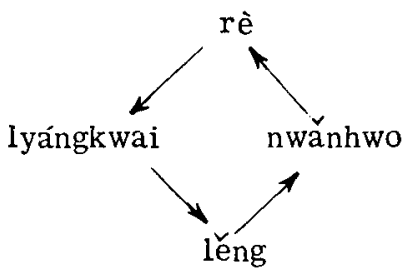

English speakers learning to control Chinese often do not use lyángkwai and nwănh̆wo in their proper relationship to $r \grave{e}$ and léng. The foregoing analysis shows us why. There is a similarity between the four weather expressions in English and in Chinese as items. But speakers of each language experience each set differently. Experiencing the weather is an act common to English speakers and Chinese speakers. But the classification of this experience between the two peoples is different and thus the linguistic distribution of the items between the two languages is different. 
Example 2. Grammar: nouns.

There are nouns and verbs in Chinese. A noun is a syntactic word which can be placed in apposition with a D-AN compound, as rén in jèi ge rén 'this man', shwěi in yi béi shwéi 'a cup of water'.5 A verb is a syntactic word which can be modified by the adverb bù (except that the verb yǒu takes méi) and can be followed by the phrase suffix $l e .^{6}$ For example:

\section{AN Noun}

1. jèi běn shū 'this book'

2. jèi jāng hwàr 'this picture'

\section{Verb}

\begin{tabular}{|c|c|c|}
\hline 1. bú & $\begin{array}{l}\text { yàu } \\
\text { yàu } \\
\text { yàu le }\end{array}$ & $\begin{array}{l}\text { 'want' } \\
\text { 'not want' } \\
\text { 'wanted' }\end{array}$ \\
\hline 2. & lái & 'come' \\
\hline bi & le & $\begin{array}{l}\text { 'not com } \\
\text { 'came' }\end{array}$ \\
\hline
\end{tabular}

Our interest in each example is the noun.

In utterances, except in citation forms, Chinese nouns may occur with or without the AN. For example:

\section{AN}

tā yàu shū $\sim$ tā yàu běn shū 'He/she wants a book.' tā yàu hwàr tā yàu jāng hwàr 'He/she wants a picture.' tã yàu byău $\sim$ tā yàu ge byău 'He/she wants a watch.'

Chinese nouns are not immediately preceded by a number. When a number occurs, the sequence is "number, AN, noun". ?

\footnotetext{
4Yuen Ren Chao, Mandarin Primer (Cambridge, Harvard University Press, 1948), p. 46. Chao uses the National Romanization in his Primer, so that his forms are ren, jeyg ren, shoei, $i$-bei shoei, yeou, and $m e i$.

5" $D-A N$ compounds are subordinate compounds of determinatives and auxiliary nouns, as $i$-tian 'one day, 'jey-kuay 'this piece.'" Chao, Primer, p. 43. Our spelling is $y t$ tiān and jèi kwài. "Determinatives and Auxiliary Nouns.--Determinatives consist of numerals and demonstratives, interrogatives, and a few other bound words ... An auxiliary noun or AN is a bound word forming, when preceded by numerals or certain other determinatives, a substantive compound, which we have called a D-AN compound." Chao, Primer, p. 45.

6Chao, Primer, p. 47.

7'yan leang-jin...'two catties of salt"" is "bookkeeping style". Chao, Primer, p. 46. Our spelling is yán lyăng jinn.
} 
For example:

$\begin{array}{llll}\text { Number } & \text { AN } & \text { Noun } & \\ \text { yī } & \text { běn } & \text { shū } & \text { 'one book' } \\ \text { lyăng } & \text { jāng } & \text { hwàr } & \text { 'two pictures' } \\ \text { sān } & \text { ge } & \text { byău } & \text { 'three watches' }\end{array}$

Whether the meaning of the number is singular or plural, the form of the AN and that of the noun following the AN remain the same.

In English, there are also nouns and verbs. Both nouns and verbs may be distinguished from each other syntactically as well as morphologically. Morphologically, nouns may occur without an ending or (with the exception of a small number,) may occur with the $\{z\}$ ending. For example:

Without an ending

With $\{z\}$ ending

book

picture

book -s

watch

picture-z

watch $-\dot{t} z$

They ordered a book.

They ordered books.

They ordered a picture.

They ordered a watch.

They ordered pictures.

They ordered watches.

Morphologically, verbs may also occur without an ending or (with the exception of modal auxiliaries) may occur with the $\{z\}$ ending or (with the exception of strong verbs) the $\left\{d{ }_{i}^{\prime}\right.$ ending. For example:

Without an ending

book

picture

watch

want

They book passages.

They picture the situations well. They watch boats. They want friends.

$\begin{array}{ll}\text { With }\{z\} \text { ending } & \text { With }\{d\} \text { ending } \\ \text { book }-s & \text { book }-t \\ \text { picture }-z & \text { picture-d } \\ \text { watch- } \dot{\text { in }} & \text { watch-t } \\ \text { want }-\mathrm{s} & \text { want-id }\end{array}$

He books passages. He booked passages. He pictures the He pictured the situations well. situations well.

He watches boats. He watched boats. He wants friends. He wanted friends.

Our interest in each example is the noun. 
In contrast to the kind of nouns that may occur without an ending or (with the exception of a small number,) may occur with the $\{\mathbf{z}\}$ ending, there is another kind of noun in English. These nouns may also occur without an ending or may occur with the $\{z\}$ ending. For example:

Without an ending

With $\{z\}$ ending

soup

tea

soup-s

juice

tea $-z$

They ordered soup.

juice-iz

They ordered tea.

They ordered juice.

They ordered soups.

They ordered teas.

They ordered juices.

However, when they occur with the $\{z\}$ ending, they are classified with book-s, picture-z, watch-iz, as count nouns. When they occur without the $\{z\}$ ending, they are referred to as mass nouns.

book

picture

watch book -s

picture-z

watch-iz

Mass nouns may be preceded by a construction containing "a number followed by a count noun". For example:

$\begin{array}{llll}\text { soup } & \text { one } & \text { bowl } & \text { of soup } \\ \text { soup } & \text { two } & \text { bowl-z } & \text { of soup } \\ \text { tea } & \text { three } & \text { cup-s } & \text { of tea } \\ \text { juice } & \text { four } & \text { glass-iz } & \text { of juice }\end{array}$


In such cases, if the number is plural in meaning, the count noun is plural in meaning and in form. The form of the mass noun remains unchanged.

Count nouns can also be preceded by a construction containing "a number followed by a count noun". For example:

$\begin{array}{llll}\text { book } & \text { one } & \text { set } & \text { of book-s } \\ \text { book } & \text { two } & \text { set-s } & \text { of book-s } \\ \text { picture } & \text { three } & \text { collection-z } & \text { of picture-z } \\ \text { watch } & \text { four } & \text { box-iz } & \text { of watch-iz }\end{array}$

Similar to the formation of the construction preceding a mass noun, when the number is plural in meaning, the count noun immediately following the number is plural in meaning and in form. The form of the count noun following the construction, however, can have the $\{z\}$ ending. The contrast between the count noun and the mass noun can be seen in the following comparison.

\begin{tabular}{|c|c|c|c|c|c|}
\hline & $\begin{array}{l}\text { Count } \\
\text { noun }\end{array}$ & $\begin{array}{l}\text { Mass } \\
\text { noun }\end{array}$ & & $\begin{array}{l}\text { Count } \\
\text { noun }\end{array}$ & $\begin{array}{l}\text { Count } \\
\text { noun }\end{array}$ \\
\hline ne & bowl & of soup & one & set & of book $-\mathrm{s}$ \\
\hline vo & bowl-z & of soup & two & set-s & of book-s \\
\hline three & cup-s & of tea & three & collection-z & of picture- \\
\hline four & glass $-\dot{t} z$ & of juice & four & box $-i z$ & of watch-iz \\
\hline
\end{tabular}

In English, a count noun can be immediately preceded by a number and a mass noun cannot. In Chinese, no noun can be immediately preceded by a number. We can put the English nouns and Chinese nouns side by side in the following way:

English

$\begin{array}{lllllll}\text { 1a. } & \text { two } & \text { books } & \text { 1b. } & \text { lyăng } & \text { běn } & \text { shū } \\ \text { 2a. three } & \text { pictures } & 2 b . & \text { sān } & \text { jang } & \text { hwàr } \\ 3 a . & \text { two bowls of soup } & \text { 3b. } & \text { lyăng } & \text { wăn } & \text { tang } \\ \text { 4a. three cups of tea } & 4 b . & \text { sān } & \text { bēi } & \text { chá }\end{array}$

English speakers learning to control Chinese orally often produce *lyăng sha and *sān hwàr for lyăng běn sha and san jang hwàr. In other words, the AN is left out. However, they do not produce *lyăng tāng and *sān chá for lyăng wăn tâng and $s \bar{a} n$ béi chá. We shall proceed to discover what native habit is 
interfering the production of the satisfactory forms in the foreign language.

It is unanimously accepted that in foreign language teaching, when there is one form in the native language but more than one in the foreign language, there is unquestionable learning difficulty. For example: native speakers of Chinese find it difficult to master book $\neq$ books for sha On the other hand, it is sometimes thought that when there is more than one form in the native language and only one form in the foreign language, there is no learning difficulty. For example: native speakers of English have no trouble in producing $s h \bar{u}$ for book $\neq b o o k s$. The first statement is an axiom; the second, however, is a gross generalization.

As a case in point, there are two distributions of nouns in English, and there is one in Chinese. Book:sh $\bar{u}$; picture:hwdr ; watch:byău; soup:tāng; tea:chá; juice; $\bar{r}$ are all nouns. In English, nouns belong to two kinds of experience: book, picture, watch; soup, tea, juice. These two function in two different ways; they have two grammatical distributions. All Chinese nouns may or may not belong to the same kind of experience; but grammatically they function the same way: there is only one grammatical distribution. At first glance it seems that there would be no problem for English speakers to produce the Chinese counterparts for two books and three pictures, since there is only one distribution of nouns in Chinese. But there is a problem.

Comparing the two languages, we find that $1 \mathrm{~b}$. lyăng bèn sh̄u and $2 \mathrm{~b} . s \bar{a} n$ jāng hwàr are similar to 1a.two books and 2a.three pictures in meaning experience, and that $3 \mathrm{~b}$.lyăng wăn tāng and 4b. sān bēi chá are similar to 3a. two bowls of soup and 4a. three cups of tea in experience classification. Hence between the two languages there is some similarity in meaning experience and in experience classification. But there is a difference in grammatical distribution between the two pragmatic similarities. $1 \mathrm{~b}$. and $2 \mathrm{~b}$. are similar to $1 \mathrm{a}$. and $2 \mathrm{a}$. in meaning experience but similar to $3 \mathrm{a}$. and $4 \mathrm{a}$. in experience classification. 


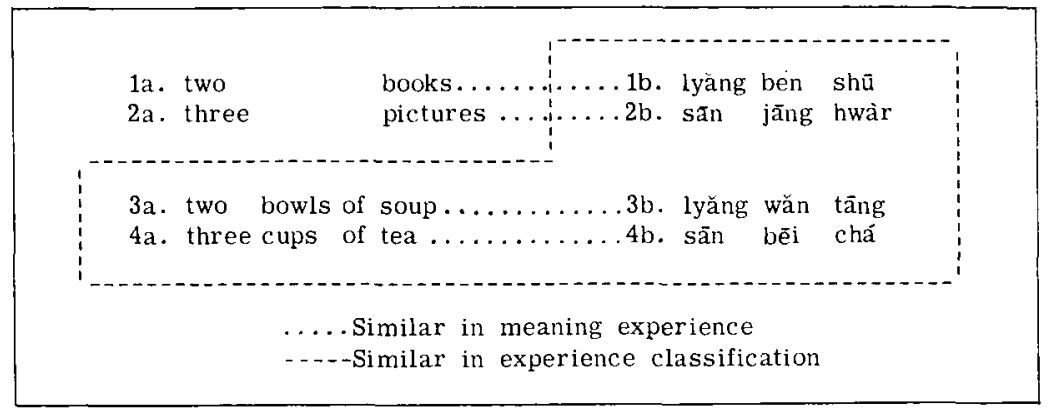

The meaning experience and the experience classification of lyăng bĕn sha and sān jäng hwàr both occur in English. However, in meaning experience, they are similar to that of count nouns; in experience classification, they are similar to that of mass nouns.

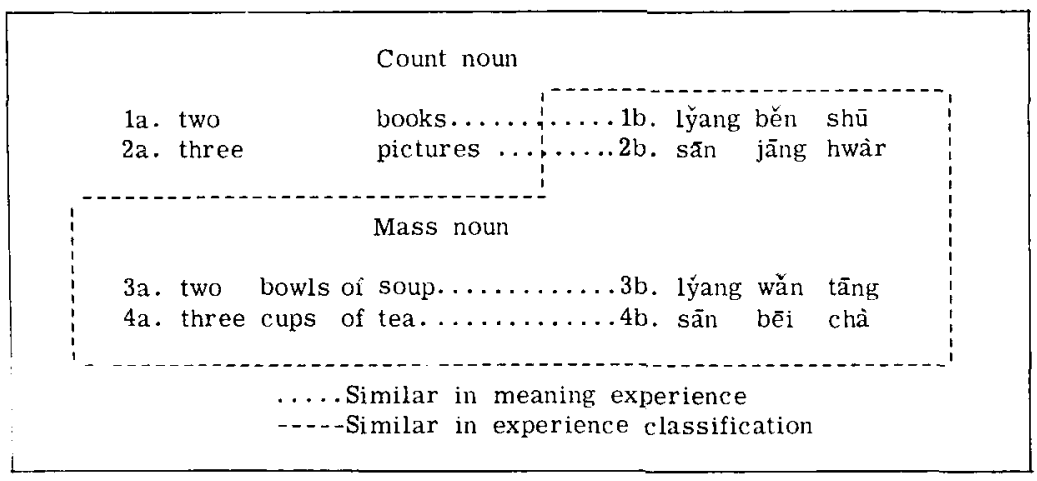

In the two languages, similar meaning experience has different experience classification. Different experience classification calls for different linguistic distribution. Similar meaning experience, similar experience classification, and similar linguistic category between languages constitute learning problems when there is difference in classification of similar meaning experience and thus difference in distribution in similar linguistic category. 
Example 3. Meaning and grammar: two quantity question expressions.

Two expressions in English that lexically indicate quantity and grammatically ask questions are how much and how many. How much implies uncountability and occurs before mass nouns. How many signals countability and precedes count nouns. For example:

How much tea

How many book-s

There is a construction which contains how many followed by a plural count noun and which occurs before a non-plural mass noun or a plural count noun. In either case, how many indicates countability, and the immediately following noun is the particularizer. For example:

How many cup-s of tea

How many pound $-z$ of tea

How many box $-\dot{i} z$ of tea

How many set-s of book-s

How many collection $-z$ of book $-\mathbf{s}$

How many case-iz of book-s

When a native speaker of English asks for quantity, he signals a choice between countability and uncountability by selecting how many for the former and how much for the latter.

Similarly Chinese has two expressions that lexically indicate

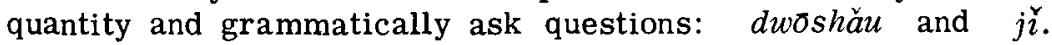
$d w \bar{s}$ shău asks for two or more new digits. It is a free form and may immediately precede a noun. For example:

dwōshău chá dwōshǎu shū
'How much tea?'

'How many books?'

$j i$ asks for one new digit (from $y \bar{i}$ 'one' through shr' 'ten') ${ }^{8}$ i.e., monomorphemic numbers or numbers with one $d \dot{z} .9 j i$ is a bound form and is bound to an ordinal signal immediately pre-

$8 d \dot{z}$ is spelled $t z y h$ in the National Romanization. "Chinese scholars recognize two kinds of word-like subunits in speech. The commonest small change of everyday speech is the monosyllable or $t z y h \ldots$. In short, a $t z y h$ plays the same social part in Chinese life as a word plays in English... we shall call tzyh a morpheme." Chao, Primer, p. 33.

${ }^{9}$ Hereafter "one digit" means "one new digit from $y i$ 'one' through shri 'ten'". 
ceding it, or to $\mathrm{AN}$ or the name of the digit immediately following it.

For example:

dì jî̀

jî bēi chá

jĭ běn shū

shŕ jì bēi chá

shr̈ jĭ běn shū

jǐ shŕ bēi chā

jî shŕ běn shū
'Number which?'

'How many cups of tea?'

'How many books?'

'Ten and how many cups of tea?'

'Ten and how many books?'

'How many tens of cups of tea?'

'How many tens of books?'

When a native speaker of Chinese asks for quantity, he chooses between an answer with one digit, and an answer with two or more digits. If the former is expected, he selects $j i$; if the latter, he uses dwōshău. Lexically both $j \grave{\imath}$ and $a w \bar{s} s h a ̆ u$ express quantity. Grammatically both express interrogation. $j \check{\imath}$ asks about a one-digit number and is a bound form. dwōshău asks about a number with two or more digits and is a free form.

The relationship between how many, how much and $j i$, , dwōshău is shown in the following diagram.

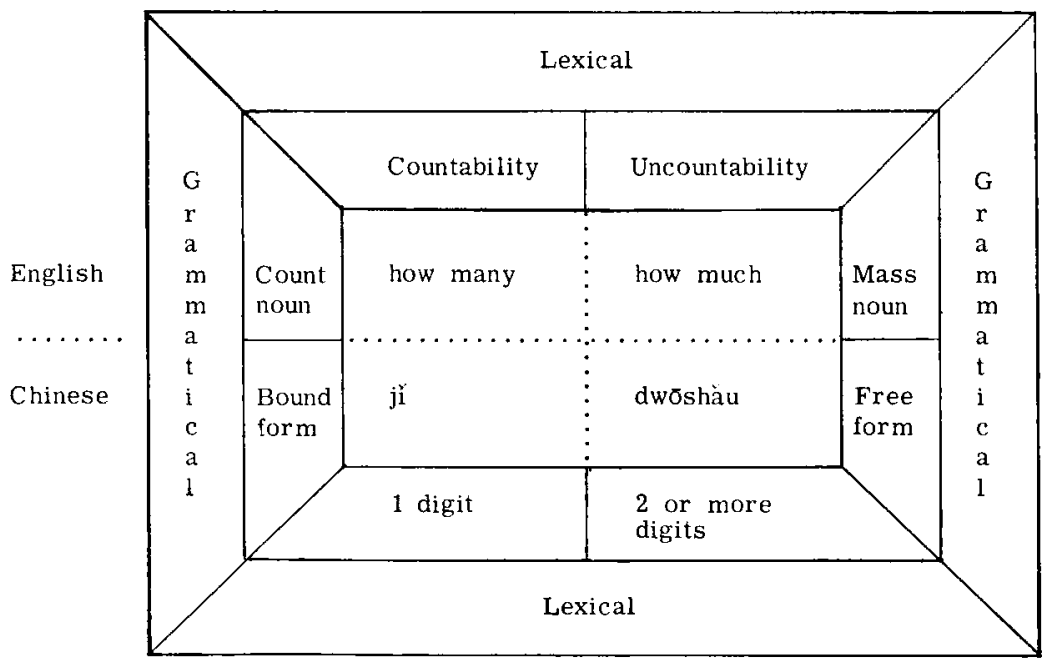

English speakers learning Chinese often fail to select the bound form $j \check{i}$ and use it as a bound form when one digit is expected in the answer, and the free form $d w \bar{s}$ shău when two or 
more are expected. Chinese speakers learning English frequently neglect to correlatehow many with count nouns and how much with mass nouns.

There is similarity between how many, how much and $j \imath$, $d w \bar{o} \operatorname{shău}$ in that they are all quantity question expressions. But as lexical items, they are different in meaning distribution. As grammatical items, they are different in linguistic distribution.

Between any two languages, there can be differences and similarities. This phenomenon can also occur between the student's native language and his foreign language. In foreign language teaching, a teacher not only must be constantly aware of the differences between the students' native language and the foreign language he is teaching but also must study the apparent similarities in the two languages in detail. Differences undoubtedly cause errors in foreign language production. Similarities, as we have seen, can also cause mistakes. For within similarities, there can be different distributions. Different distributions are also error-causing factors.

Foreign language learning is a discipline. The learner must say what the native speakers of that language say, strange as some of the linguistic features may seem to him. It is also essential that he attempts to categorize as the native speakers do, unusual as some of the ways may appear to him. For between peoples, similar meaning experience can have different experience classification; between languages, similar linguistic categories can have different linguistic distributions. In order to speak a foreign language properly, the learner must master the linguistic distributions of that language. Such mastery can be more easily attained if he attempts to understand the way native speakers classify experience. And similarities with different distribution can thus be acquired with less difficulty. 